\title{
PIIISGUC.ORG
}

"iş, GÜÇ" ENDÜSTRi iLişKILERI VE INSAN KAYNAKLARI DERGISi

"IS, GUC" INDUSTRIAL RELATIONS AND HUMAN RESOURCES JOURNAL

\section{Algılanan Örgütsel Politikanın Örgütsel Vatandaşlık Davranışı İle İlişkisinde Adaletin Rolü}

\author{
Arş. Gör. Özgür AYHAN \\ KHO Savunma Bilimleri Enstitüsü \\ Doç. Dr. Sait GÜRBÜZ \\ KHO Savunma Bilimleri Enstitüsü
}

Temmuz/July 2014, Cilt/Vol: 16, Sayı/Num: 3, Page: 76-93

ISSN: 1303-2860, DOI: 10.4026/1303-2860.2014.0256.x

Makalenin on-line kopyasına erişmek için / To reach the on-line copy of article:

http://www .isguc.org/?p=article\&id=556\&cilt=16\&sayi=3\&yil=2014

Makale İçin İletişim/Correspondence to:

Özgür AYHAN, Kara Harp Okulu, email: oayhan@kho.edu.tr 


\author{
Temmuz/July 2014, Cilt/Vol: 16, Say1/Num: 3, Page: 76-93 \\ ISSN: 1303-2860, DOI: 10.4026/1303-2860.2014.0256.x
}

İş, Güç, Endüstri İlişkileri ve İnsan Kaynaklan Dergisi, yılda dört kez yayınlanan hakemli, bilimsel elektronik dergidir.

Çalışma hayatına ilişkin makalelere yer verilen derginin temel amacı, belirlenen alanda akademik gelişime ve paylaşıma katkıda bulunmaktadır.

İş, Güç, Endüstri İlişkileri ve İnsan Kaynaklan Dergisi, 'Türkçe' ve 'İngilizce' olarak ikidilde makale yayinlanmaktadır.

Dergimiz İş, Güç; ulusal ve uluslararası birçok indekste taranmaktadır. (Cabells Directory, Ebsco Socindex, Index Islamicus, Index Copernicus, Worldwide Political Science Abstracts, Sociological Abstract, Ulakbim Sosyal BilimlerVeritan, Asos Index)

\section{Editörler Kurulu / Editorial Board}

Aşkın Keser (Uludă̆ University)

K.Ahmet Sevimli (Uludă̆ University)

Şenol Baştürk (Uludăg University)

\section{Editör/Editor in Chief}

Şenol Baştürk (Uludăg University)

\section{Uygulama / Design}

Yusuf Budak (Kocaeli University)

Tarandı̆̆ı Indeksler/Indexes

ASOS INDEX

CABELLS DIRECTORY

EBSCO SOCINDEX

Index ISLAMICUS

Index COPERNICUS

Sociological Abstract

ULAKBİM Sosyal Bilimler

Veritanı

Worldwide Political Science

Abstracts

\author{
Yayın Kurulu / Editorial Board \\ Yrd.Doç.Dr.Zerrin Firat (Uludăg University) \\ Prof.Dr.Aşkın Keser (Uludağ University) \\ Prof.Dr.Ahmet Selamo $\breve{g l u}$ (Kocaeli University) \\ Yrd.Doç.Dr.Ahmet Sevimli (Uludağ University) \\ Doç.Dr.Abdulkadir Şenkal (Kocaeli University) \\ Doç.Dr.Gözde Yılmaz (Marmara University) \\ Yrd.Doç.Dr.Dr.Memet Zencirkıran (Uludăg University)
}

Uluslararası Danışma Kurulu / International Advisory Board

Prof.Dr.Ronald Burke (York University-Kanada)

Assoc.Prof.Dr.Glenn Dawes (James Cook University-Avustralya)

Prof.Dr.Jan Dul (Erasmus University-Hollanda)

Prof.Dr.Alev Efendioğlu (University of San Francisco-ABD)

Prof.Dr.Adrian Furnham (University College London-Ingiltere)

Prof.Dr.Alan Geare (University of Otago-Yeni Zellanda)

Prof.Dr. Ricky Griffin (TAMU-Texas AEM University-ABD)

Assoc. Prof. Dr. Diana Lipinskiene (Kaunos University-Litvanya)

Prof.Dr.George Manning (Northern Kentucky University-ABD)

Prof. Dr. William (L.) Murray (University of SanFrancisco-ABD)

Prof.Dr.Mustafa Özbilgin (Bruner University-UK)

Assoc. Prof. Owen Stanley (James Cook University-Avustralya)

Prof.Dr.Işık Urla Zeytinoğlu(McMaster University-Kanada)

$$
\begin{aligned}
& \text { Ulusal Danışma Kurulu / National Advisory Board } \\
& \text { Prof.Dr.Yusuf Alper (Uludağ University) } \\
& \text { Prof.Dr.Veysel Bozkurt (İstanbul University) } \\
& \text { Prof.Dr.Toker Dereli (Işık University) } \\
& \text { Prof.Dr.Nihat Erdoğmuş (İstanbul Şehir University) } \\
& \text { Prof.Dr.Ahmet Makal (Ankara University) } \\
& \text { Prof.Dr.Ahmet Selamo ğlu (Kocaeli University) } \\
& \text { Prof.Dr.Nadir Suğur (Anadolu University) } \\
& \text { Prof.Dr.Nursel Telman (Maltepe University) } \\
& \text { Prof.Dr.Cavide Uyargil (İstanbul University) } \\
& \text { Prof.Dr.Engin Yıldırım (Anayasa Mahkemesi) } \\
& \text { Doç.Dr.Arzu Wasti(Sabancı University) }
\end{aligned}
$$

Dergide yaymlanan yazılardaki görüşler ve bu konudaki sorumluluk yazarlarna aittir.

Yayınlanan eserlerde yer alan tüm içerik kaynak gösterilmeden kullanılamaz.

All the opinions written in articles are under responsibilities of the outhors.

The published contents in the articles cannot be used without being cited 


\title{
Algılanan Örgütsel Politikanın Örgütsel Vatandaşlık Davranışı İle İlişkisinde Adaletin Rolü*
}

\author{
Arş. Gör. Özgür AYHAN \\ KHO Savunma Bilimleri Enstitüsü \\ Doç. Dr. Sait GÜRBÜZ \\ KHO Savunma Bilimleri Enstitüsü
}

\begin{abstract}
The objective of this study was to determine the influence of perceived organizational politics on organizational citizenship behaviour and to reveal the mediating role of organizational justice on that relationship. The research hypotheses were tested among 229 white collar employees at the companies in public sector in the province of Ankara and Istanbul. Research results demonstrated that perceived organizational politics had significant effects on organizational justice however there was no relationship between perceived organizational politics and organizational citizenship behaviour. Furthermore, mediating role of organizational justice was not supported. Implications for future research on perceived organizational politics and practice were discussed.
\end{abstract}

Key words: perceived organizational politics, organizational justice, organizational citizenship behavior

Öz

Bu çalışmanın amacı; algılanan örgütsel politikanın (AÖP), örgütsel vatandaşlık davranışı (ÖVD) üzerindeki etkisini tespit etmek ve bu ilişkide örgütsel adaletin aracılık rolünün olup olmadı̆̆ını belirlemektir. Bu amaçla oluşturulan hipotezler, İstanbul ve Ankara'da faaliyet gösteren kamu kurumlarından kolayda örnekleme yöntemi ile seçilmiş 229 beyaz yakall çalışandan oluşan bir örneklem üzerinde test edilmiştir. Elde edilen bulgular neticesinde, AÖP'nin örgütsel adalet üzerinde anlamlı bir etkisinin olduğu, ancak ÖVD üzerinde anlamlı bir etkisinin bulunmadı̆̆ tespit edilmiştir. Ayrıca, örgütsel adaletin aracılık rolü tespit edilememiștir. Araştırmada AÖP konusunda yapılacak çalışmalara öneriler ile uygulamaya olan katkısına değinilmiştir.

Anahtar Kelimeler: algılanan örgütsel politika, örgütsel adalet, örgütsel vatandaşlı davranışı

*Bu çalışmanın ilk hali, 15-16 Kasım 2013 tarihleri arasında düzenlenen 1. Örgütsel Davranış Kongresinde sunulmuştur." 
"iş, GÜç" Endüstri iliş̧kileri ve İnsan Kaynakları Dergisi

"IS, GUC" Industrial Relations and Human Resources Journal
Temmuz/July 2014 - Cilt/Vol: 16 - Sayı/Num: 03 Sa yfa/Page:7 6-93, DOI: 10.4026/1303-2860.2012.0255.x

\section{GíRiş}

Örgütsel davranış yazını incelendiğinde son yıllarda örgütlerin aydınlık tarafı kadar karanlık tarafının da araştırılmaya başlandığı görülmektedir. Ancak bazı konuların, karanlık veya aydınlık bölgede olduğunu söylemek oldukça güçtür. $\mathrm{Bu}$ bağlamda örgütsel politika konusu örgütsel davranış araştırmalarında nispeten arafta kalan ve özellikle son yirmi yılda üzerine çalışmalar yapılan konulardan biridir. Örgütsel politika (ÖP) genel olarak işgörenlerin şahsi çıkarlarını korumak ve geliştirmek için sergiledikleri davranışlar olarak tanımlanmaktadır (Vigoda, 2000). Yazında ÖP'nin örgüt araştırmalarının karanlık bölgesinde mi yoksa aydınlık bölgesinde $\mathrm{mi}$ olduğuna dair bir fikir birliğinden söz edilemez. Zira ÖP'nin iş tutum ve davranışlarına olumsuz etkilerinin olduğuna dair bazı araştırma bulguları (örn.,Vİgoda, 2000; Ferris ve Kacmar, 1992; Ayhan ve Gürbüz, 2013) olmakla birlikte, iş tutumlarının ÖP'den etkilenmediğini (örn., Parker vd., 1995), hatta iş tutumları ile ÖP arasında olumlu ilişki olduğunu savunan (Yen vd., 1999) bazı araştırma sonuçları da bulunmaktadır. Haliyle ÖP'nin, örgütsel davranış araştırmalarının loş kısmında konumlandığı söylenebilir. ÖP'nin tam olarak doğru yerde konumlandırılması için ÖP-iş tutumları ve davranışları üzerinde daha fazla araştırmaya ihtiyaç olduğu değerlendirilmektedir. Dolayısıyla bu çalışmada ÖP ile işgören davranışları ilişkisi üzerine odaklanılacaktır. Çünkü ÖP-iş tutumları ve davranışları üzerine yapılan çalışmalar genelleme yapmaya yetecek mahiyette değildir. Bunun nedeni yapılan çalışmaların ağırlıklı olarak Kuzey Amerika bağlamında ve özel sektörden seçilmiş örneklem üzerinde yapılmış olmasıdır. Farklı bağlam ve sektörlerde yapılan çalışmaların sayısının ise oldukça az olduğu görülmektedir (örn.,Vigoda, 2000; Ram ve Prabhakar, 2010; Ayhan ve Gürbüz, 2013). İş yapıları ve özellikleri bakımından farklılıklar taşıyan özel sektör ve kamu sektörü üzerine yapılacak çalışmalar ÖP'nin iş tutum ve davranışları ilişkisinin daha açık ortaya konulması için önem taşımaktadır. Sargut'un (2010) dinamik iç gruplardan oluşan, adam kayırmacılığın hâkim olduğunu doğu kültürünün bir parçası olarak tanımladığı Türkiye bağlamında ÖP'nin, işgörenlerin tutum ve davranışlarının şekillenmesinde önemli bir yere sahip olması beklenmektedir. Ancak ÖP konusunda doğu toplumları bağlamında yapilan çalışmaların sayısı oldukça azdır (Vigoda, 2000; İşcan, 2005; Ram ve Prabhakar, 2010). Benzer şekilde, ÖP konusunda salt kamu sektörünü hedef alan araştırma sayısı oldukça sınırlıdır (örn. Parker vd., 1995; Vigoda, 2000).

$\mathrm{Bu}$ çalışmanın iki temel amacı bulunmaktadır. Birincisi, sosyal mübadele kuramından hareket ederek işgörenlerin örgütsel politika algılarının, örgütsel vatandaşlık davranışları üzerindeki etkisini tespit etmektir. İkincisi ise algilanan örgütsel politikanın, örgütsel vatandaşlık davranışı üzerindeki etkisinde, örgüsel adaletin aracılık edip etmediğini ortaya çıarmaktır. Çalışmanın örgüt yazınında çıktıları konusunda fikir birliği olmayan ÖP konusunda yapılan sınırlı çalışmalara katkısı olacağı düşünülmektedir. Ayrıca AÖP konusunda Türkiye bağlamında sınırlı sayıda çalışma olması ve var olan çalışmaların hiçbirinin kamu sektörü üzerinde yapılmamış olması nedeniyle bu araştırmanın ilgi yazına mütevazı da olsa bir katkı sağlayacağı beklenmektedir.

\section{Kuramsal Çerçeve}

\subsection{Algılanan Örgütsel Politika}

ÖP yazını incelendiğinde, bu konuya 1990'l y yllar itibarıyla odaklanılmaya başlandığı görülecektir. ÖP yazını 20 yıllık bir geçmişe sahip olmasına rağmen, ÖP'nin tanımı üzerinde bir fikir birliğine oluşmadığ belirtilmektedir. (Drory ve Romm 1989; Vigoda-Gadot, 2010). Buchanan (2008)'in örgütsel politikanın yaygın olarak olumsuz bir terim olarak görülmesine rağmen örgütün çıkarlarını koruma ve geliştirme gibi olumlu sonuçları olabileceği belirtmektedir. Ancak, ÖP'ye dair yapılan tanımlamalarda genellikle ÖP'nin olumsuz yönüne vurgu yapıldığı görülmektedir.ÖP ile ilgili yapılan 
tanımlamalarda araştırmacıların vurguladığı ortak noktaların şahsi çıkar koruma ve geliştirme faaliyetleri ile sosyal etkileme taktikleri olduğu görülmektedir (Cropanzano vd., 1995). Mayes ve Allen (1977) ÖP tanımının hem mikro hem de makro düzeyde bir analiz içermesi gerektiğini ve politik olan ve politik olmayan davranışları ayırt edici özellikte olması gerektiğini savunmaktadır. Ayrıca ÖP'nin karar verme sürecinde şekillendiği de araştırmacılar tarafından ifade edilmektedir. $\mathrm{Bu}$ bağlamdan hareketle, Kacmar ve Ferris (1991) ÖP'yi karar verme sürecini güç kullanarak belli kişi ya da grupların çıkarları doğrultusunda yönlendirmek olarak tanımlarken, Drory (1993) gayri resmi temelli ve çelişkili yönetim tarzlarıyla ortaya çıkan şahsi çıkar koruma ve geliştirme çabaları şeklinde tanımlamıştır. En çok kabul gören tanımlamalardan birinin sahibi olarak kabul edilen Vigoda'nın (2000) da aynı noktalara vurgu yaparak, ÖP'yi işgörenlerin gözünde diğer işgörenlerin şahsi çıkarlarını korumak ve geliştirmek için sergiledikleri davranışlar olarak tanımladığı görülmektedir.

\section{2. Örgütsel Adalet}

Araştırmanın bir diğer değişkeni olan örgütsel adalet (ÖA) konusu ise 50 yılı aşkın bir süredir hem kuramsal açıdan hem de davranışsal açıdan incelen bir konudur. Adaletin kavramsallaştırılma süreci Homans (1961)'la başlamış, Adams'ın eşitlik teorisi (1965) ile konuya gösterilen ilgi artmış ve Greenberg (1987)'in geliştirdiği sınıflandırma ile birlikte kavramsallaştırma çalışmaları devam etmiştir. Greenberg (1987)'in sinıflandırmasından yola çıkılarak ÖA, bireylerin ödül ve kaynakların dağıtımı ile de bu dağıtım sürecine yönelik öznel algıları ve görüşler olarak tanımlanabilir. Coquitt ve ark. (2011) bu tanımlamayı daha net ifade edecek şekilde ÖA'yı alt boyutları ışı̆̆ında tanımlayarak örgütsel adaletin, kaynak ve ödüllerin dağıtımı, bu dağıtımı sürecine ve bu süreçteki kişiler arası etkileşime dair oluşan algı olarak tanımlamıştır. Yazında örgütsel adalete dair pek çok model ve sinıflandırma olmasına rağmen en yaygin kabul gören boyutlandırma Niehoff ve Moorman (1993)'in çalışması etrafında şekillenmiştir. Niehoff ve Moorman (1993), ÖA'yı iki alt boyut altında incelemiş ve bu boyutları dağıtım adaleti ve prosedür (süreç) adaleti olarak ikiye ayırmıştır. Ancak bazı araştırmacılar prosedür adaletini de ikiye ayırarak prosedür ve etkileşim adaleti olarak adlandırmışlardır (Luo, 2007). Dağıtım adaleti, örgütlerdefayda ve zararın dağılımına dair algılamalar üzerine inşa edilirken sadece ödüllerin dağılımına değil aynı zamanda iş yükünün de dağılımına dair algilamalara işaret edilmektedir (Colquitt, 2001). Dağıtım adaletinin oluşmasında eşitlik, eşit paylaşım ve ihtiyaç kuralları ön plana çıkmaktadır (Luo, 2007). Grenberg'in (1987) süreç kontrolü gibi hem yapısal elementlere hem de iş ilişkilerindeki adalet algısının belirleyicisi olma özelliğine vurgu yaptığı prosedür adaleti ise karar mekanizmasinın uygulama ve faydaları belirleme sürecinde adil oluşunu temsil etmektedir (Luo, 2007). Prosedür adaletinin en işlevsel özelliklerinden biri, çalışanlarda oluşan yüksek prosedür adaleti algısının grup üyelerine değer verildiği algisının oluşmasına netice vermesidir (Niehoff ve Moorman, 1993). Son olarak etkileşim adaleti de süreçlerin sosyal yönünü teşkil eder ve süreçlerdeki etkileşimin kalitesi olarak değerlendirilebilir (Luo, 2007). Örgütsel adalet yazını incelendiğinde etkileşim adaleti bazı araştırmacılar tarafından prosedür adaleti içerisinde (Niehoff ve Moorman, 1993) , bazı araştırmacılar tarafından ise tıpkı prosedür adaleti gibi örgütsel adaletin ayrı bir boyutu olarak (Colquitt vd., 2011) değerlendirilmektedir.

\section{3. Örgütsel Vatandaşlık Davranışı}

Araştırmanın bağımlı değişkenini olan örgütsel vatandaşlık davranışı (ÖVD), ilk olarak Organ tarafından ortaya atılmış bir kavramdır (Organ, 1983). Farklı tanımlamalar olmakla birlikte, ÖVD örgüt performansının yer aldığı sosyal ve psikolojik çevreyi destekleyen davranışlar olarak tanımlanmaktadır (Organ, 1988). Bu noktada en önemli hususlardan biri, ÖVD'nin gönüllü olarak sergilenen davranışlar olmasıdır (Gürbüz, 2007). Yazında ÖVD ile ilgili pek çok boyutlandırma olmakla birlikte, bu 
boyutlandirmalar arasında en yaygin kabul göreni ve diğer boyutlandırmalarda temel alınanı Organ'ın diğergamlık, nezaket, vicdanlllık, sivil erdem ve centilmenlik boyutlarından oluşan boyutlandırmasıdır (Gürbüz, 2007). Bu boyutlandırmayı temel alan ve bu çalışmada bağımlı değişken olarak ele alınan ÖVD-örgüt ve ÖVD-birey boyutlandırması Williams ve Anderson (1991)'ın boyutlandırmasıdır. Söz konusu boyutlandırmaya göre ÖVD hedeflenen kitle ya da guruba göre adlandırılmakta, bireye yönelik davranışlar ÖVD-bireyi, örgüte yönelik sergilenen davranışlar ise ÖVD-örgütü oluşturmaktadır (Wiliams ve Anderson, 1991). $\mathrm{Bu}$ boyutlandırmanin Organ (1988)'in boyutlandırmasıyla benzer yönü ise ÖVDbirey diğerkamlık ve nezaket boyutlarından, ÖVD-örgüt ise vicdanlılık, sivil erdem ve centilmenlik boyutundan beslenmesidir. $\mathrm{Bu}$ çalışmada öz değerlendirmeler ele alınacağı ve iç gurupların bireye yönelik ÖVD sergileme ihtimalinin yüksek olmasından dolayı ÖVDbirey boyutundaki davranışlar ele alınmıştır.

\section{Araștırmanın Hipotezleri ve Modeli}

AÖP'nin-işgören tutum ve davranışları ile olan ilişkisinin kuramsal bir temele dayandırılmasinda sosyal mübadele kuramı'nın (Blau, 1964) uygun bir bakış açısı vereceği değerlendirilmektedir. Sosyal mübadele kuramına göre, bireyler örgütlerine yaptıkları girdiler karşılığında örgütlerinden elde ettikleri çıktılarda mütekabiliyetin olmasını isterler. Bazı örgüt üyelerinin girdileri karşısında daha çok çıktı elde etmesi, diğer örgüt üyeleri tarafından rahatsız edici bir durum olarak değerlendirilebilir. Bir örgütte yapmış olduğu girdiyle almış olduğu çıktı arasında orantısızlık olduğunu düşünen bireylerin varlığı o örgütte mütekabiliyetin olmadığı ve iş ortamının adaletsiz olduğu algisina sebep olabilir (Blau, 1964). Chanve ark. (2009) örgütsel politika algısının yüksek olduğu örgütlerde ödüllerin dağılımında, örgüt içi ilişkilerin, gücün ve nesnel olmayan faktörlerin anahtar öğeler olduğunu savunmaktadır. Girdileri ile çıktıları arasında adaletli ve mütekabiliyet esaslı bir ilişki olmadığı algısına sahip işgörenlerin moral düzeyleri düşmekte, ödül dağılımını keyfi ve adaletsiz algilamakta ve bunun neticesinde örgütsel adalet alg1 düzeyleri düşmektedir (Rosen vd., 2006). AÖP'nın bazı iş tutum ve davranışları üzerinde yukarıda bahsedilen mütekabiliyet çerçevesinde olumsuz etkileri olacağı yapılan çalışmalarla ortaya konulmuştur (örn. Cropanzano vd., 1997; Vigoda, 2000; Miller vd., 2008; İşcan, 2005;Bodla ve Danish, 2009).

Özdevecioğlu'nun (2002) özel sektörün politik etkiye açık oluşuna dair vurgusu, kamuda çalışan işgörenlerin örgütsel politika algılarının yüksek çıkma ihtimaline işaret etmektedir. Çünkü seçim ve terfi kararlarında kıdemin ve ilişkilerin önemli olması ve işgörenlerin performanslarını yükselmeleri ve ödül almalarında önemli bir etken olmamasından dolayı işgörenleri örgütsel politika algıları yükselmektedir. Bu durumun iş performansında düşüşlere sebep olduğu gibi bazı iş tutum ve davranışları üzerinde de menfi tesire sahip olması beklenmektedir.

Sargut (2010) Türk toplumunu doğu bağlamında ele alırken, Türk toplum yapısında dinamik iç grupların hakim olduğunu, kendisi kaybetmesi pahasına karşısındakinin de başarısızlığını istediğini savunmaktadır. Ona göre iç gruplar diğer gruplara firsat vermemek için grubun diğer üyelerine daha fazla yardım etme eğilimindedirler. Bu durum grup içi yardımlaşmanın artmasına, bir diğer ifadeyle ÖVD-bireyin artmasına sebep olmaktadır. Ancak benzer durumun ÖVD-örgüt için söylenmesi mümkün değildir. Bu sebeple bu çalışmada ÖVD-birey'in yüksek çıkması beklenmektedir.

AÖP'nin olumsuz etkilediği iş tutum ve davranışlarının başında tutum olarak bağlllık, işten ayrılma niyeti gibi değişkenler gelirken davranış olarak ise ilk olarak ÖVD gelmektedir. Hisiung ve ark. (2012), AÖP-ÖVD ilişkisi örgütler için önem arz eden ve aralarında bir ilişki olması beklenen değişkenler olmasına rağmen, bu ilişkinin yeterince araştırılmadığını savunmaktadır. Aradaki ilişkinin doğası gereği işgörenlerin örgütlerine dair düşük AÖP'ye sahip olmaları 
onların performanslarını artırarak ÖVD sergilemesine sebep olması beklenmektedir (Randall vd., 1999). Cropanzano ve ark. (1997) yapmış oldukları çalışmada AÖP ile ÖVD arasında bir ilişki tespit etmemiş olmasına rağmen Randall ve ark. (1999) AÖP ile ÖVD'nin iki boyutu (ÖVD-birey, ÖVD-örgüt) arasında güçlü bir olumsuz ilişki tespit etmiştir. Buradan hareketle;

$H_{1}=$ Algilanan örgütsel politika ile örgütsel vatandaşlık davranış arasında olumsuz yönde anlamlı yönde bir ilişki vardır.

Yazında ÖVD'nin örgütsel adaletten nasıl etkilendiği birçok çalışmayla ortaya konulmuştur (örn. Fahr, Podsokoff ve Organ, 1990;Niehoff ve Moorman, 1991). Moorman ve Niehoff (1991) özellikle prosedür adaletinin ve etkileşim adaletinin ÖVD üzerindeki etkisine işaret etmiştir. Bununla birlikte etkileşim adaletinin, ÖVD üzerindeki etkisine yönelik de çalışmalar bulunmaktadır (örn, Sert, 2013; Songür vd., 2008). AÖP-ÖA arasındaki ters yönlü ilişki dikkate alındığında AÖP'nın prosedür ve etkileşim adaletini olumsuz yönde etkileyeceği, prosedür ve etkileşim adaletinin de ÖVD'ye etki edip, daha önce ÖVD üzerindeki aracılık özelliği vurgulanan ÖA'nın (Niehoff ve Moorman, 1993), AÖP-ÖVDilişkisi üzerinde de aracılık yapacağı beklenmektedir. Bunun sebebi ÖA'nın, AÖP'nin bağımlı değişken üzerindeki etkisini anlamsızlaştırıcı ya da azaltıcı özelliğe sahip olmasıdır. İş çevrelerini adaletli olarak algılayan işgörenlerin örgütsel politika algilarında kısmi bir düşüş görülebilmekte, hatta ÖA, AÖP'nin etkisini anlamsızlaştırabilmektedir (Byrne, 2005). Buradan hareketle;

$\mathrm{H}_{2}=$ Prosedür adaleti ile örgütsel vatandaşlık davranışı arasında olumlu ve anlamlı bir ilişki vardır.

$H_{3}=$ Prosedür adaletinin algilanan örgütsel politika-örgütsel vatandaşlık davranışı ilişkisinde aracılık rolü vardır.

$H_{4}=$ Etkileşim adaleti ile örgütsel vatandaşlık davranışı arasında olumlu ve anlamlı bir ilişki vardır.
$H_{5}=$ Etkileşim adaletinin algilana örgütsel politika- örgütsel vatandaşlik davranışı ilişkisinde aracılık rolü vardır.

AÖP-ÖA ilişkisi yazında incelenmiş ve yapılan çalışmalarda aradaki olumsuz ilişki ortaya konulmuştur (Andrews ve Kacmar, 2001; Harris vd., 2007; Byrne, 2005). Cropanzanove ark. (1997) yüksek AÖP düzeyinin,işgörenlerin örgütsel adalet ve eşitlik düzeylerine dair algılamalarının düşmesine sebep olacağını savunmaktadır. Bir diğer önemli husus ise yukarıda bahsedilen sosyal mübadele ilişkisinde AÖP-ÖA ilişkisinin belirleyici bir rolünün olabileceği, AÖP örgüt içindeki sosyal mübadele ilişkisini zayıflatırken ÖA bu ilişkiyi güçlendirmesi hususudur (Harris vd.,2007).Andrew ve Kacmar (2001) AÖP'nın, ÖA boyutlarından prosedür adaleti ile göreceli olarak daha yüksek ilişki içerisinde olduğunu savunmaktadır. Onlara göre örgüt içi terfilerin belirlenmesinde kurallar yerine örgüt içi politikaya değer verilmesi, çalışanların iş çevrelerini ve süreçleri adaletsiz algilamalarına neden olmaktadır. Yani prosedür adaletinin AÖP-ÖVD ilişkisini etkilemesi beklenen bir durumdur. Buradan hareketle;

$H_{6}=$ Algilanan örgütsel politika ile prosedür adaleti arasında olumsuz ve anlamlı bir ilişki vardır.

Byrne (2005) örgütsel politikanın örgütsel adalete olan etkisini Tyler ve Lind (1992)'in ilişkisel modeli ile açıklamaktadır. Söz konusu modele göre işgörenler adaleti, mertebelerini yükselttiği, görüşlerinin önemsenmesini sağladığı ve karar verme sürecinde tarafsızlığ 1 tesis ettiği için önemsemektedirler. Bu sayede işgörenler, yöneticiler ve örgütle olumlu bir ilişki kurmuş olurlar ki bu da ilişkinin kalitesiyle alakalı olması sebebiyle etkileşim adaletinin önemine işaret etmektedir (Byrne, 2005). Etkileşim adaletinin bir diğer önemli yanı ise AÖP'nin olumsuz çıktılarını izaleeden bir özelliğe sahip olmasıdır (Byrne, 2005). Buradan hareketle;

$H_{7}=$ Algılanan örgütsel politika ile etkileşim adaleti arasında olumsuz ve anlamlı bir ilişki vardır. 
Sosyal mübadele kuramı ve yukarıda verilen, daha önce yapılan çalışmalardan hareketle oluşturulan araştırma modeli Şekil 1 de gösterilmiştir.

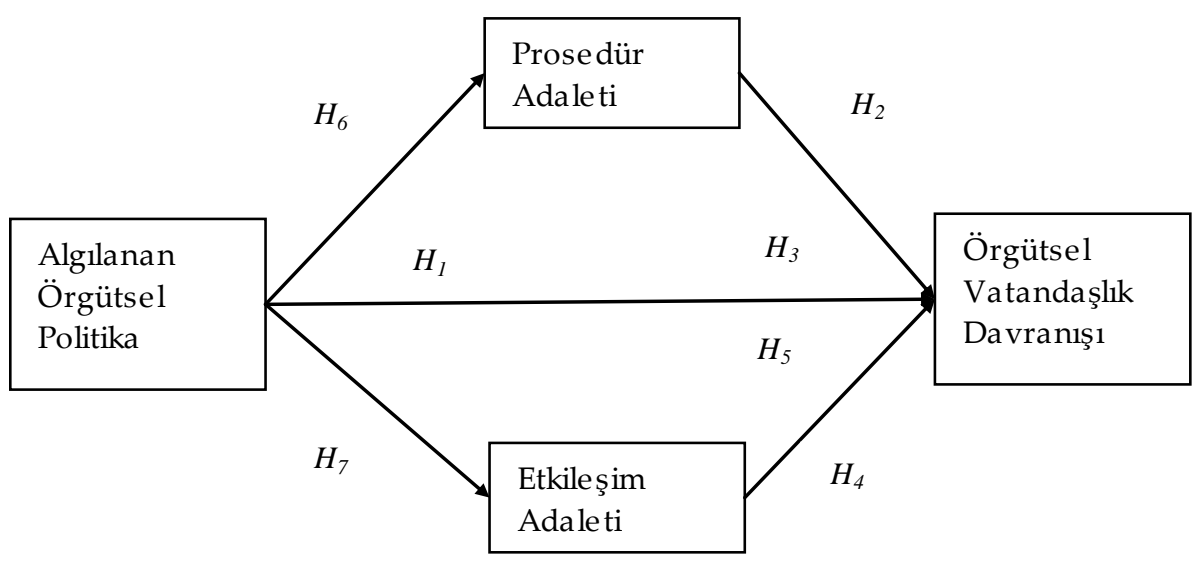

Şekil 1. Araştırmanın Modeli

\section{Araştırmanın Yöntemi}

\section{1. Örneklem}

$\mathrm{Bu}$ çalışmanın araştırma evrenini İstanbul ve Ankara'da bulunan kamu çalışanları oluşturmaktadır. Özdevecioğlu'nun (2002) Türk kamu sektörünün politik etkiye daha açı bir yapıda olduğu ifadesinden hareketle araştırmanın Türk kamu çalışanları üzerinde yapılması uygun görülmüştür. Bazı kamu kurumlarının personel sayısını, güvenlik vb. gerekçelerle bildirmemesinden dolayı araştırmanın evreni tam olarak bilinmemektedir. Bu yüzden araştırmanın kolayda örnekleme yöntemiyle seçilmiş 250 kişilik bir örneklem üzerinde uygulanması uygun görülmüştür. Bu kapsamda İstanbul ve Ankara'da bulunan beş farklı kamu örgütüne 250 adet anket gönderilmiştir. Gönderilen anketlerin 241 adedi geri dönmüş ve toplanan anketlerden 229 adet kullanılabilir veri elde edilmiştir. Anketlerin geri dönüş oranı \%91.6 olarak hesaplanmıştır. Araştırmaya katılan katılımcıların ortalama yaşı 34, ortalama deneyimleri ise 10 yıldır. Mevcut örgütlerinde geçirdikleri süre ise 7 yıl olarak hesaplanmıştır. Ayrıca katılıcıların 160'ı (\%70) erkek, 69'u (\%30) kadındır.Katılımcıların eğitim durumlarına bakıldığında $10(\% 4,37)$ kişi lise diplomasına sahipken, 119 (\%51,96) kişi lisans, 100 (\% 43,7 kişi ise yüksek lisan/doktora derecesine sahiptir.

\subsection{Veri Toplama Araçları}

Araştırmada veri toplama aracı olarak anket tekniği kullanılmıştır. Anket iki bölümden oluşmaktadır. Birinci bölümde demografik değişkenlere yönelik sorular yer alırken ikinci bölümde araştırmaya konu olan değişkenlere yönelik ölçekler yer almaktadır.

\subsubsection{Algılan Örgütsel Politika Ölçeği}

İşörenleri örgütsel politika algıları Kacmar ve Ferris (1991) tarafından geliştirilmiş ölçek ile ölçülmüştür. Ölçek, yükselmek için sergilenen politik davranışlar, genel politik davranışlar, ücret ve terfi kazanmaya yönelik politik davranışlar, çıkarcılık ve üstün ve mevkidaşların sergiledikleri politik davranışlar olmak üzere 5 boyuttan oluşmaktadır. Kacmar 
ve Ferris (1991) tarafından başta 40 soru olarak hazırlanan bu ölçek zaman içinde geçerlilik çalışmalarıyla revize edilmiştir. Ölçek aynı boyutlar altında Türkçe olarak Menişa (2006) ve Ayhan(2013) tarafindan 24 soru olarak kullanılmış ve güvenilirlik ve geçerlilik bakımından uygun olduğu raporlanmıştır. Araştırmada kullanılan ölçeğin güvenilirlik analizi yapılmış ve hem 5 alt boyutun, hem de toplam ölçeğin cronbach alfa değerlerleri .70'in üzerinde olduğu tespit edilmiştir.

\subsection{2. Örgütsel Adalet Ölçeği}

Çalışanların örgütsel adalet algıları Niehoff ve Moormon'in (1993) geliştirmiş olduğu 20 soruluk ölçek ile test edilmiştir. Araştırmada söz konusu ölçeğin tamamı kullanılmamış 5 sorudan oluşan dağıtım adaleti çıkartılmış ve 15 sorudan oluşan prosedür ve etkileşim adaleti analiz edilmiştir. Ölçeğin alt boyutlarına ait güvenilirlik değerleri .90'ın üzerindedir. Ölçeğin Türkçeye uyarlaması Gürbüz ve Mert (2009) tarafından yapılmıştır.

\subsection{3. Örgütsel Vatandaşlık Ölçeği}

Örgüt üyelerinin sergilemiş oldukları örgütsel vatandaşlık davranışlarını ölçmek için Gürbüz (2007) tarafından Türkiye de kullanılan Orgon ve Konovsky (1989), Wiliams ve Anderson (1991) ve Moormon ve Blakely (1995) gibi araştırmacıların kullanmış oldukları ölçeklerden istifade edilerek geliştirilmiştir. İşörenlerin örgütsel politika ve adalet algılamaları gibi öznel değerlendirmelerine odaklanılmasından dolayı ÖVD ölçülürken de bireye yönelik ÖVD'ye bakmanın daha doğru olacağı görüşünden hareketle, orjinal ölçek 5 boyuttan oluşmasına rağmen, çalışmamızda Williams ve Anderson'un (1991) boyutlandırmasında temel aldığı ÖVD-birey boyutunu oluşturan diğerkamlık ve nezaket boyutları kullanılmıştır. Ölçek 6 sorudan oluşmaktadır. Güvenilirlik analizi neticesinde elde edilen cronbach alfa değeri .818'dir

\section{3. İşlem}

Araştırmada kullandığımız verileri analiz etmek için LISREL 8.8 (Jöreskog ve Sörbom, 2006) ve SPSS 18 paket programları kullanılmıştır. Çalışmada kullandığımız ölçeklerin güvenilirliğini test etmek için içsel tutarlılıklarına bakılmış ve cronbach alfa katsayıları hesaplanmıştır. Ölçeklerin geçerliliği yapısal eşitlik modelinin bir uygulaması olan doğrulayıcı faktör analizi (DFA) ile yapılmıştır. DFA analizinde, maksimum olasılık hesaplaması (Maximum likelihood estimation) ile oluşturulmuş kovaryans matrisi kullanılmıştır. Ölçeklerin DFA analizleri kapsamında uyum iyiliği değerleri olarak $\chi 2, \chi 2^{\prime}$ nin serbestlik derecesine bölümü, Root Mean Square Error of Approximation (RMSEA), Comparative Fit Index (CFI) ve Goodness of Fit Index (GFI) değerleri kullanılmıştır. Değişkenler arasındaki ilişki korelasyon ve regresyon analizi ile test edilmiştir.

\section{Bulgular}

\section{1. Ölçüm Araçlarının Geçerliliğine} İlişkin Bulgular

Araştırmada kullanılan ölçüm araçlarının geçerliliği doğrulayıcı faktör analizi ile test edilmiştir. DFA sonuçları Tablo1’de gösterilmektedir. Uyum iyiliği değerlerine ilişkin kabul edilebilir değer aralığı noktasında pek çok tartışma olmakla birlikte, yaygin şekilde kabul gören görüşe göre $\chi 2 / d f$ oranının 5 den küçük, RMSEA'nın .08'den küçük CFI ve GFI'nın .90 dan büyük olması kabul edilebilir uyuma işaret etmektedir (örn., Brown, 2006; Hu ve Bentler, 1999; Kline, 2005). Tablo 1'de sunulan sonuçlar incelendiğinde AÖP'nin 5 boyutlu yapısına dair elde edilen uyun iyiliğgi değerlerinden GFI (.86) dışındaki değerlerin $(\chi 2 / d f=1.80 ; \quad R M S E A=.06 ; \quad C F I=.91)$ yazında kabul gören değerlerin üzerinde olduğu görülmektedir. Söz konusu değerler AÖP ölçeğinin 5 boyutlu yapısının bu çalışmada doğrulandığını göstermektedir. Örgütsel adalet ölçeğinin iki boyutlu yapısına dair elde edilen uyum iyiliği değerleri $(\chi 2 / d f=2.06$; RMSEA $=.06 ; \quad$ CFI $=.97 ; \quad G F I=.91)$ ile ÖVD ölçeğine dair elde edilen uyum iyiliği değerlerinin $(\chi 2 / d f=2.13 ;$ RMSEA $=.07 ; \mathrm{CFI}=.98$; GFI= .98) de yazında kabul edilebilir değerlerin üzerinde olduğu Tablo 1 de görülmekte ve bu bulgular ÖA'nın iki boyutlu yapısı ve ÖVD'nin 
tek boyutlu yapısının doğrulandığına işaret

etmektedir.

Tablo.1. Araştırmanın Değişkenlerine Ait Doğrulayıcı Faktör Analizi Sonuçları

\begin{tabular}{lcccccc}
\hline Değişkenler & $\chi 2$ & $\mathrm{df}$ & $\Delta \chi 2 / \mathrm{df}$ & \multirow{2}{*}{ RMSEA } & CFI & GFI \\
\hline Algilanan Örgütsel Politika (5 & 428.4 & 238 & 1.80 & .06 & .91 & .86 \\
Boyutlu) & 179.04 & 87 & 2.06 & .06 & .97 & .91 \\
Örgütsel Adalet (2 Boyutlu) & 17.09 & 5 & 2.13 & .07 & .98 & .98 \\
Örgütsel Vatandaşlık Davranışı &
\end{tabular}

\subsection{Korelasyon ve Tanımlayıcı İstatistiki Bulgular}

Araştırmaya dahil edilen değişkenlere ait ortalama değerleri, standart sapma değerleri, Pearson korelasyon ve Cronbach alfa güvenilirlik katsayıları Tablo 2'de gösterilmektedir. Boyut ortalamalarındaki 3'ün altında kalan değerler AÖP için olumlu duruma PA, EA ve ÖVD için olumsuz duruma işaret etmektedir. Ortalama değerler açısından kamu çalışanlarının algılarına bakıldığı zaman, kamu çalışanlarının örgütsel politika algılarının üçün üzerinde olduğu (ort.=3.05; s.s.= .668), çalıştıkları ortamı kısmen politik olarak algıladıkları görülmektedir. Katılımcıların adalet algılarında ise farklı bir durum göze çarpmaktadır. Katılımcıların prosedür adaleti algılarının düşük iken (olumsuz) (ort=2.76; s.s.= .916), etkileşim adaleti algılarının görece yüksek (olumlu) (ort.=3.10; s.s.= .101) olduğu tespit edilmiştir. Deneklerin ÖVD ortalamasına bakıldığında ise çoğunluğunun ÖVD sergileyen çalışanlar olduğu görülmektedir (ort.=3.82; s.s.= .701).

Tablo.2. Araştırmanın Değişkenlerine Ait Ortalama, Standart Sapma, Korelasyon ve Güvenilirlik Değerleri

\begin{tabular}{lcccccc}
\hline Değişkenler & Ort. & SS & 1 & 2 & 3 & 4 \\
\hline Algılanan ÖrgütselPolitika & 3.05 & .668 & $(.926)$ & & & \\
Prosedür Adaleti & 2.76 & .916 & $-.602^{*}$ & $(.902)$ & $.807^{*}$ & $(.938)$ \\
Etkileşim Adaleti & 3.10 & .101 & $-.513^{*}$ & .110 & $.144^{* *}$ & $(.818)$ \\
ÖrgütselVatandaşlı & 3.82 & .701 & .081 & .10 & \\
Davranışı & & & &
\end{tabular}

${ }^{*} p<.01$ düzeyinde anlamlı ${ }^{* *} p<.05$ düzeyinde anlamlı. Parantez içindeki değerler Cronbach alfa güvenilirlik katsayisidir.

Değişkenler arası ilişkilere bakıldı̆̆ında pearson korelasyon değerleri değişkenler arasındaki sınırlı ilişkileri göstermektedir. Araştırmanın bağımsız değişkeni olan algılan örgütsel politika ile bağımlı değişken olan ÖVD arasında anlamlı bir ilişki tespit edilememiştir ( $\mathrm{r}=0.081 ; p>.05)$. Ancak algılanan örgütsel politika ile prosedür adaleti arasında orta düzeyde ve anlamlı bir ilişki tespit edilmiştir $(\mathrm{r}=.602 ; p<.01)$. Benzer ilişki algılanan örgütsel politika ve etkileşim adaleti arasında da bulunmaktadır. Algılanan örgütsel politika ile etkileşim adaleti arasında orta düzeyde ve anlamlı bir ilişki bulunmaktadır $(\mathrm{r}=.513 ; \quad p<.01)$. Araştırmamızın bağımlı değişkeni olan örgütsel vatandaşlık davranışının sadece etkileşim adaleti ile anlamlı bir ilişkisinin oluşu ( $\mathrm{r}=.144 ; p<.05)$ diğer değişkenlerle olan ilişkisinin anlamsız çıkması beklenmeyen ve ilginç bir bulgudur. 
Öte yandan değişkenlerin içsel tutarlılık değerleri yazında kabul gören değerlerin (cronbach $\alpha>$.70) üzerinde olduğu Tablo 2 de parantez içerisindeki değerlerden anlaşılmaktadır.

\subsection{Regresyon Analizi ve Hipotez} Testlerine İlişkin Bulgular

Araştırmanın hipotezleri hiyerarşik regresyon analizleri ile test edilmiştir. Kurulan modelleri test etmek için öncelikle demografik, değişkenler kontrol altına alınmış ve bağımlıbağımsız değişkenlerin analizine devam edilmiştir. Kurulan ilk 6 modelde diğer değişkenlerin, bağımlı değişken olan ÖVD üzerindeki etkisi test edilmiştir. Son dört modelde ise AÖP'nin prosedür ve etkileşim adaleti üzerindeki etkisi yordanmıştır. Söz konusu analizlere ilişki elde edilen değerler Tablo.3 ve Tablo.4'te gösterilmektedir.

Tablo.3. Örgütsel Vatandaşlık Davranışı Üzerinde Etkileri Olan Değişkenlere Ait Hiyerarşik Regresyon Analizi Sonuçları

\begin{tabular}{|c|c|c|c|c|c|c|}
\hline \multirow[b]{2}{*}{ Değişkenler } & \multicolumn{6}{|c|}{ Örgütsel Vatandaşlık Davranışı } \\
\hline & $\begin{array}{c}\text { Model } 1 \\
\beta\end{array}$ & $\begin{array}{c}\text { Model } 2 \\
\beta\end{array}$ & $\begin{array}{c}\text { Model3 } \\
\beta\end{array}$ & $\begin{array}{c}\text { Model } 4 \\
\beta\end{array}$ & $\begin{array}{c}\text { Model } 5 \\
\beta\end{array}$ & $\begin{array}{c}\text { Model } 6 \\
\beta\end{array}$ \\
\hline Yaş & -.015 & -.022 & -.015 & .005 & -.015 & .003 \\
\hline Cinsiyet & .003 & .003 & .003 & .007 & .003 & .015 \\
\hline Eğitim & -.019 & -.010 & -.019 & -.026 & -.019 & -.030 \\
\hline Çalışma Sür. & .023 & .019 & .023 & .017 & .023 & .008 \\
\hline Toplam Den. & .077 & .075 & .077 & .060 & .077 & .072 \\
\hline AÖP & - & .070 & - & - & - & - \\
\hline $\mathrm{PA}$ & - & - & - & .108 & - & - \\
\hline EA & - & - & - & - & - & $.145^{* *}$ \\
\hline $\mathrm{R}^{2}$ & .007 & .012 & .007 & .018 & .007 & .028 \\
\hline $\bar{F}$ & .311 & .435 & .311 & .689 & .311 & $1.050^{* *}$ \\
\hline$\Delta R^{2}$ & - & .005 & - & .011 & - & .021 \\
\hline$\Delta \mathrm{F}$ & - & .124 & - & 378 & - & .739 \\
\hline Düz. $\mathrm{R}^{2}$ & -.015 & -.015 & -.015 & -.008 & -.015 & .001 \\
\hline
\end{tabular}

$\mathrm{n}=229 ;{ }^{*} p<.01$ düzeyinde anla mlı ${ }^{* *} \mathrm{p}<.05$ düzeyinde anlamli; AÖP: Algılanan ÖrgütselPolitika PA: Prosedür Adaleti; EA: Etkileşim Adaleti

Araştırmanın ilk hipotezi Model 1 de demografik değişkenler kontrol altına alındiktan sonra Model 2 de test edilmiştir. Yapılan analiz neticesinde AÖP'nin ÖVD üzerinde anlamlı bir etkisine rastlanmamıştır $\beta$ $=0.70 ; \quad p>05) . \mathrm{Bu}$ sonuçla birlikte $H_{1}$ ("Algılanan örgütsel politika ile örgütsel vatandaşlık davranış arasında olumsuz yönde anlamlı yönde bir ilişki vardır") desteklenmezken aracılık ilişkisine dair oluşturulan hipotezlerde $\left(H_{3}, H_{5}\right)$ de reddedilmiştir. Bunun sebebi, bağımsız değişkenin bağımlı değişken üzerindeki etkisinde başka bir değişkenin aracılık etkisinin olabilmesi için ilk şart bağımsız değişkenin bağımlı değişken üzerinde anlamlı etkiye sahip olması gerekir. İkinci şart aracı değişkenin bağımlı değişken üzerinde anlamlı bir etkiye sahip olması gerekir ve üçüncü olarak da aracı değişkenin denklem girmesiyle birlikte bağımsız değişkenin bağımlı değişken üzerindeki etkisinin ortadan kalması ya da anlamlı düzeyde azalması gerekmektedir (Baron ve Kenny, 1986). Yapilan analiz neticesinde bahsedilen kurallardan ilkinin gerçekleşmemiş olması aracılık ilişkisine dair oluşturulan $H_{3}$ ("Prosedür adaletinin algılanan örgütsel politika-örgütsel vatandaşlık davranışı ilişkisinde aracılık rolü vardır") ve $H_{5}{ }^{\prime}$ in ("Etkileşim adaletinin algılanan örgütsel politika-örgütsel vatandaşlık davranışı 
ilişkisinde aracılık rolü vardır.") desteklenmediği anlamına gelmektedir.

Prosedür $\left(H_{2}\right) \quad$ ve etkileşim $\left(H_{4}\right)$ adaletinin örgütsel vatandaşlık davranışı üzerindeki etkisi sırasıyla Model 4 ve Model 6 da test edilmiştir.Analiz sonuçları Tablo 3'de gösterilmektedir. Anılan değişkenlerin ÖVD üzerindeki etkisinde demografik değişkenlerin etkisini tespit etmek maksadiyla Model 3 ve Model 5 oluşturulmuş ve demografik değişkenlerin bağımlı değişken üzerinde anlamlı etkiye rastlanmamıştır. Dördüncü modelde, prosedür adaletinin örgütsel vatandaşlık üzerindeki etkisine bakılnıştır. Ancak elde edilen sonuç prosedür adaletinin örgütsel vatandaşlık davranışı üzerinde anlamlı bir etkisinin olmadığını göstermektedir $(\beta=0.108 ; p>.05)$. Örgütsel vatandaşlık davranışının bağımlı değişken olduğu bir diğer modelde etkileşim adaletinin örgütsel vatandaşlik üzerindeki etkisine bakılmıştır. Model 6'da gösterilen sonuçlara göre örgütsel vatandaşlık davranışının etkileşim adaletinden etkilendiği tespit edilmiştir $(\beta=0.145 ; p<.05)$. Ancak etkileşim adaletinin örgütsel vatandaşlık davranışı üzerindeki etkisinde açıllanan varyansın \%1 in altında olması (Düz. $\mathrm{R}^{2}=.001, \mathrm{~F}(5)=1.050$, $p<.05)$ söz konusu etkinin düşük düzeyde kaldığına işaret etmektedir. Bu sonuçlardan hareketle $\mathrm{H}_{2}{ }^{\prime}$ nin ("Prosedür adaleti ile örgütsel vatandaşlık davranışı arasında olumlu ve anlamlı bir ilişki vardır") desteklenmediği , $H_{4}$ ün ("Etkileşim adaleti ile örgütsel vatandaşlık davranışı arasında olumlu ve anlamlı bir ilişki vardır") ise desteklendiği görülmektedir.

Tablo.4. AÖP'nin Prosedür Adaleti ve Etkileşim Adaleti Üzerine Etkilerini Gösteren Hiyerarşik Regresyon Analizi Sonuçları

\begin{tabular}{|c|c|c|c|c|}
\hline \multirow{3}{*}{ Değişkenler } & \multicolumn{2}{|c|}{ Prosedür Adaleti } & \multicolumn{2}{|c|}{ Etkileşim Adaleti } \\
\hline & Model 7 & Model 8 & Model 9 & Model 10 \\
\hline & $\beta$ & $\beta$ & $\beta$ & $\beta$ \\
\hline Yaş & -.193 & -.135 & -.127 & -.077 \\
\hline Cinsiyet & -.037 & -.039 & -.085 & -.087 \\
\hline Eğitim & .065 & -.016 & .077 & .008 \\
\hline Çalışma Sür. & .051 & .086 & .100 & .130 \\
\hline Toplam Den. & .160 & .178 & .038 & .053 \\
\hline AÖP & - & $-.622^{*}$ & & $-.529^{*}$ \\
\hline $\mathrm{R}^{2}$ & .019 & .390 & .020 & .288 \\
\hline $\mathrm{F}$ & $.858^{*}$ & $23.641^{*}$ & .898 & $14.963^{*}$ \\
\hline$\Delta R^{2}$ & - & .371 & - & .268 \\
\hline$\Delta \mathrm{F}$ & - & $22.738^{*}$ & - & $14.065^{*}$ \\
\hline Düz.R2 & -.003 & .373 & -.002 & .269 \\
\hline
\end{tabular}

Son olarak 6 . ve 7 . hipotezleri test etmek için yapılan analizlere ilişkin elde edilen sonuçlar Tablo.4 te gösterilmektedir. Kurulan modellerde algilanan örgütsel politikanın prosedür adaleti ve etkileşim adaleti üzerindeki etkisi test edilmiştir. Model 7 ve Model 9 da demografik değişkenlerin sırasıyla prosedür adaleti ve etkileşim adaleti üzerinde anlamlı bir etkisinin olup olmadığı test edilmiş ve anlamlı bir etki tespit edilmemiştir. Model 8 de algılanan örgütsel politikanın prosedür adaleti üzerindeki etkisine bakılmıştır $\left(H_{6}\right)$. Kurulan model prosedür adaletinin algilanan örgütsel politikadan etkilendiğini 
göstermektedir $(\beta=-.622 ; p<.01)$. Açıklanan varyans da .373 olarak hesaplanmıştır (Düz. $\left.\mathrm{R}^{2}=.373, \mathrm{~F}(5)=23.641, p<.01\right)$. 10. modelde ise algılanan örgütsel politikanın etkileşim adaleti üzerindeki etkisine bakılmıştır $\left(H_{7}\right)$. Elde edilen sonuçlar etkileşim adaletinin algılanan örgütsel politikadan etkilendiğini $(\beta=-.529$; $p<.01)$ ve etkileşim adaletinin \%26.9 luk kısmının algılanan örgütsel politika tarafından açıklandığı tespit edilmiştir (Düz. $\mathrm{R}^{2}=.269$, $\mathrm{F}(5)=14.963, p<.01)$. Bu sonuçla birlikte $H_{6}$ ("Algılanan örgütsel politika ile prosedür adaleti arasında olumsuz ve anlamlı bir ilişki vardır") ve $H_{7}$ ("Algılanan örgütsel politika ile etkileşim adaleti arasında olumsuz ve anlamlı bir ilişki vardır") desteklenmiştir.

\section{Tartışma ve Sonuç}

$\mathrm{Bu}$ araştırmada; kamu çalışanlarının örgütsel politika algılarının, prosedür adaleti, etkileşim adaleti ve örgütsel vatandaşlık davranışı üzerindeki etkisinin olup olmadı̆̆ı, prosedür adaleti ve etkileşim adaletinin, AÖPÖVD ilişkisinde aracılık rolünün bulunup bulunmadığı ortaya konulmaya çalışılmıştır. Araştırmanın hipotezleri İstanbul ve Ankara'da bulunan kamu kuruluşlarında çalışan 229 kamu çalışanı üzerinde test edilmiştir.

Elde edilen bulgular neticesinde AÖP'nin ÖVD üzerinde etkili olduğuna dair oluşturulan hipotez $\left(\mathrm{H}_{1}\right)$ desteklenmemiştir. Bu bulgu ile aracilık etkisinin ilk şartı olan koşul (Baron ve Kenny, 1986) yerine getirilmediğinden, aracılığa dair oluşturulan hipotezler de $\left(\mathrm{H}_{5}\right.$ ve $\left.\mathrm{H}_{7}\right)$ desteklenmemiştir. Ancak işgörenlerin örgütsel politika algilarının, onların prosedür ve etkileşim adaleti algıları üzerinde etkili olduğuna dair kurulan hipotezler $\left(\mathrm{H}_{2}\right.$ ve $\left.\mathrm{H}_{3}\right)$ desteklenmiş AÖP'nin adalet açısından önemi bir kez daha ortaya konulmuştur. Bununla birlikte etkileşim adaletinin ÖVD üzerinde anlamlı bir etkiye sahip olması, bu doğrultuda oluşturulan hipotezin $\left(\mathrm{H}_{6}\right)$ desteklendiğini göstermektedir.

Araştırma neticesinde AÖP-ÖVD ilişkisi ile PA-ÖVD ilişkisine dair hipotezlerin desteklenmemesi ilginç ve beklenmeyen bulgulardır. Desteklenmeyen hipotezlerin neden desteklenmediğine dair olası sebepleri sıralanacak olursa; AÖP -ÖVD ilişkisi tam olarak ortaya konulmamış olması ilk olarak düşünülebilir. Yazında AÖP'nin ÖVD üzerinde anlamlı bir etkisinin olduğu savina rağmen (örn. Randall vd., 1999) arada anlamlı bir ilişki olmadığına dair görüşler de (örn. Cropanzano vd., 1997) bulunmaktadır. Elde ettiğimiz sonuçlar neticesinde yazında var olan tartışmaya bir katkı yaparak AÖP'nin ÖVD üzerinde anlamlı bir etkisinin olmadığına dair görüşün bu çalışma için geçerli olduğu sonucuna ulaşılmıştır. Var olan tartışmadan bir genellemeye gidilebilmesi için farklı örgütlerde ve farklı bağlamlarda daha fazla çalışmanın yapılması gerekmektedir.

İkincisi ÖVD'nin doğasının
araştırmanın
anlamlandırılmasında ve kurulan hipotezlerin neden desteklenmediğinin anlaşılmasında önemli bir yere sahip olduğu düşünülmektedir. Grant ve Mayer (2009) işgörenlerin ÖVD sergilemesini iki neden bağlamıştır. Bunlardan birincisi örgütsel vatandaşlık güdüleriyle, ikincisi izlenim yönetimi güdüleridir. Ancak ÖVD sergilenirken hangi güdünün hâkim olduğunun tespiti zordur. Bunun sebebi bireyler vatandaşlık davranışını sergilerken bazen örgütsel vatandaşlık güdüsüyle bazen de izlenim yönetimi güdüsüyle hareket edebilmektedir. Elde niyet ölçer gibi bir şey olmadığı müddetçe ÖVD'nin hangi güdüyle sergilendiğini tam olarak belirlemek mümkün değildir (Grant ve Mayer, 2009). ÖVD'nin doğasındaki bu zorluğun AÖP-ÖVD ilişkisini etkileyebileceği düşünülmektedir. Çünkü sergilenen ÖVD izlenim yönetimi güdüsüyle yapılabileceği düşüncesi AÖP'nin artmasına sebep olacaktır. Ancak örgütsel vatandaşlık güdüsü ise AÖP'nin düşmesini gerektirecektir. Buradaki çıkmazın aradaki ilişkiyi bozacağı düşünülmektedir. Ayrıca ÖVD yüksek olduğu zaman sergilenen davranışlar örgütsel politikanın artmasına da sebep olabilir. Söz gelimi ÖVD kapsamında fazladan mesaiye kalan bir çalışan diğerleri tarafından yanlış değerlendirilip, diğer çalışanların örgütsel politika algılarının yükselmesine sebep olabilir. AÖP-ÖVD ilişkisinin anlamlı 
çıkmamasında ÖVD'nin doğasındaki bu özelliklerin önemli bir yere sahip olduğu düşünülmektedir.

Bir diğer önemli sebep ise örgütsel adalet ile ÖVD arasındaki ilişkide ortaya çıkmaktadır. Yazın incelendiğinde örgütsel adalet ve örgütsel vatandaşlık davranışına dair yapılan meta analizlerinde örgütsel adaletin üç alt boyutunun da ÖVD ile aynı düzeyde ilişkiye sahip olmadığı görülmektedir. Yapılan çalışmaların çoğunluğunda ÖVD'nin en çok etkileşim adaletiyle, devamında prosedür adaleti ile ve en az da dağıtım adaleti ile ilişkili oluğu ortaya koyulmuştur (Sert, 2013) Bu çalışmada da ÖVD etkileşim adaletiyle prosedür adaletine göre daha yüksek ilişkilidir. Bu çalışmaya dağıtım adaletinin olmayışı genel bir değerlendirme yapmamıza olanak vermemektedir. Ancak EA-ÖVD anlamlı ilişkisi PA-ÖVD anlamsız ilişkisiyle birlikte değerlendirildiğinde çıkan sonuç anlamlanmaktadır.

Dördüncü sebep olarak, işgörenlerin ölçekleri doldururken kendilerini olduğu gibi ifade edememiş olmaları düşünülebilir. İşgörenler AÖP ile ilgili soruları cevaplarken, yönetimden korkma, örgütsel politika vb. nedenlerden dolayı samimi cevaplar vermemiş olabilirler. Bununla birlikte ÖVD ile ilgili sorular cevaplanırken de işgörenlerin sosyal beğenirlik etkisiyle var olan durumdan ziyade olması gereken durumu dikkate alarak soruları değerlendirmiş olabilirler.

Son olarak, araştırmanın yapıldığı bağlamın, araştırma üzerinde etkisinin de araştırmamızın sonuçlarını değerlendirme konusunda önemli olduğu kanısındayız. ÖVD ölçeği, daha önce Türkiye bağlamında denenmiş olmasına rağmen içerdiği ifadeler açısından ortak yöntem varyansına sebep olabilecek niteliktedir. Türkiye bağlamında işgörenlerin olumsuz olarak adlandırılabilecek davranışları yapsa dahi ifade etmekten çekinmesi beklenmektedir. Örneğin işe geç kalan bir işgörenin bunu kabul etmeyeceği, iş ortamında pek çok kez bir çok kişinin gözlemleyebileceği bir durumdur. Aynı şekilde her işgören, iş yükü ağır çalışanlara yardım edeceğini söylemesine rağmen bu durumun her zaman gerçekleşmediği bilinmektedir. Haliyle katılımcıların soruları cevaplarken mevcut bağlamdan uzaklaşamayacağı gelecek çalışmalarda farklı bağlamların da eklenmesiyle birlikte farklılık olup olmadığına bakılarak daha sağlıklı sonuçlara ulaşılabileceği değerlendirilmektedir. Bununla birlikte işgörenler ÖP'ye dair algıları yüksek olmasına rağmen "kol kırılır yen içinde kalır" düşüncesiyle, AÖP'ye rağmen ÖVD sergilemeye devam edebilirler.

Araştırmanın yazına katkısına gelinecek olursa; bu çalışmayla birlikte AÖPÖVD ilişkisinin genellenebilmesi için henüz erken olduğu, böyle bir genellemenin yapılabilmesi için daha birçok çalışmaya ihtiyaç duyulduğunun ortaya konulması yazına önemli bir katkı olarak düşünülmektedir. Ayrıca Vigoda'nın (2000) kamu çalışanlarının örgütsel politika algısı üzerine yapmış olduğu ve yazında sınırlı çalışma vurgusuna bir katkı olarak Türkiye bağlamında kamu çalışanlarının örgütsel politika algılarının incelenmiş olması hem ulusal hem de uluslararası yazın için önemli olduğu düşünülmektedir. Bu çalışma yazında adaletin aracılık etkisi üzerine var olan yaygın görüşün işlerliği noktasında önemli bir soru işareti olarak değerlendirilebilir. Bununla birlikte işgörenlerin ÖVD sergilemelerinde amirleriyle olan etkileşimin örgütsel politika algılarından daha önemli olduğu ortaya konulmuştur. Son olarak, AÖP'nin adalet üzerindeki etkisi bu çalışmayla da birlikte kanıtlanmıştır.

Çalışmada elde edilen bulgular uygulamaya dönük bazı öneriler getirmektedir. İşgörenlerin amirleri ile olan ilişkilerindeki kalite onların ÖVD sergilemesinde etkilidir. İşgörenlerin örgütsel politikadan bağımsız olarak amirlerinin kendilerine nazik davranmaları durumunda, mütekabiliyet çerçevesinde örgütü benimseyip ÖVD sergileyeceği düşünülmektedir. $\mathrm{Bu}$ bulgudan hareketle, örgütlerde karar vericilerin adil bir iş ortamı oluşturmaları ve üst-etkileşiminde adaletten taviz vermemeleri, amirlerin astlarına nazik davranmalarının 
sağlanmaya çalışılması gerekir. ÖVD'nin gönüllü sergilenen davranışlar olması sebebiyle işgörenlerin küstürülmemesi önemli bir hususdur.

Sargut (2010)'un Türk toplumuna dair dinamik iç grupların etkisinde ve adam kayırmacilığın gözlemlendiği Türk toplumuna dair görüşünün yüksek örgütsel politika düzeyi ile desteklendiği görülmektedir. Ayrıca Özdevecioğlu'nun (2002) kamu sektörünün politik etkiye açık olduğu iddiası da bu çalışmada desteklenmektedir. Kamu sektöründe terfi karalarında performanstan ziyade kıdeme bakılması ve başarsızlığa bir yaptırım uygulanmazken, başarının da gerektiği gibi ödüllendirilmemesi işgörenlerin örgütsel politika algılarının yüksek çıkmasının beklendiği şekilde gerçekleşmiştir.

Örgütsel vatandaşlık davranışının örgütsel politika algısının yüksek çıkmasına rağmen yüksek çıkması ise Sargut'un (2010)bakış açısıyla konuya yaklaşıldığı zaman anlaşılmaktadır. Şöyle ki, doğu toplumunda örgütler dinamik iç gruplar tarafından yönlendirilir. İç gruplar kendi çıkarlarını koruma doğrultusunda faaliyette bulunurken grup üyelerine yardimcı olup onları kayırırken, diğer grupları engellemeye çalışacaktır. İç grupta yer alan üyelerin aksayan üyelere yardımcı olmak için gerekli özveriyi göstererek örgütsel vatandaşlık davranışı sergilemeleri beklenen bir durumdur. Bu sebeple hem algilanan örgütsel politika düzeyi, hem de örgütsel vatandaşlık davranışının yüksek olması olağan bir durum olarak değerlendirilmektedir.

$\mathrm{Bu}$ çalışmanın bazı kısıtları da bulunmaktadır. Araştırmanın örneklemi ilk kısıtımızdır. Zaman ve maliyet gibi etmenler sebebiyle araştırmaya konu örneklemin sadece İstanbul ve Ankara'dan seçilmesi olması ve belli bir sayıda kalması araştırmanın genellenebilmesi için bir kısıt teşkil etmektedir.
Gelecekte yapilacak çalışmalarda kamu çalışanlarını da örgüt özelliklerine göre çeşitlendirilerek, farklı bağlamların eklenmesiyle genelleme bakımından önemli sonuçlar elde edilebilir.

İkinci kısıt olarak katılımcıların değişkenlere yönelik tutumlarıdır. $\mathrm{Bu}$ çalışmada kesitsel veri toplanmış olup, öz değerlendirme yöntemi uygulanarak öznel değerlendirmelere ulaşılmıştır. Bu yöntemle elde edilen verilerin araştırmaya konu olan değişkenlerin arasındaki ilişkinin büyüklüğünü etkileyebilmektedir. Haliyle elde edilen bulgular değerlendirilirken bu durum dikkate alınmalıdır. Araştırmanın kesitsel bir çalışma olması da elde edilen değişkenler arasındaki ilişki üzerinde etkili olmaktadır. Anlık durumlar deneklerin algiları üzerinde etkili olmaktadır. Verilerin aynı kişilerden farklı zamanlarda toplanarak boylamsal bir çalışma yapılması bu kısıtı ortadan kaldırabilir.

Bu çalışmada değişkenlere ait bazı alt boyutların kapsam dışında tutulmuş olması bir diğer kısıt olarak düşünülebilir. Örgütsel adalet boyutlarından dağıtım adaletinin ÖVD üzerinde anlamlı bir etkiye sahip olup olmayacağı önem taşımaktadır. ÖVD-örgüt boyutunun gelecek çalışmalarda ele alınması ÖVD'nin daha iyi yordanmasına katkı sağlayabilir. Gelecek çalışmalarda cinsiyet dengesinin kurulması da bu araştırmanın kısıtlarından bir tanesi olan cinsiyet yanlılığını gidermiş olacaktır.

Sonuç olarakbu çalışmada AÖP'nin ÖVD üzerinde anla mlı bir etkisinin olma dığını, ÖVD'nin a raştırma kapsamındaki değişkenlerden sadece etkileşim adaletinden etkilendiği, AÖP'nin PA ve EA üzerinde önemli bir etkiye sahip olduğu ortaya konulmuştur. Bu araştırma, AÖP-ÖVD ilişkisine dair tartışmalara kamu örneklemi ve Türkiye bağlamıaçısından katkı yapılmıştır. Ayrıca yazında AÖP-örgütsel adalet ilişkisindeki genel kabulün bu çalışmada da desteklendiği görülmüştür 


\section{Kaynakça}

Ayhan, Ö. ve Gürbüz, S. (2013). Algılanan örgütsel politikanın çalışanların işten ayrılma niye tine etkisinde duygusal bağlilığın rolü. Kamu ve özel sektör çalışanları üzerine bir araştırma. 21. Yönetimve Organizasyon Kongresi. 30 Mayıs-1 Haziran, Kütahya.

Ayhan, Ö. (2013). Algılanan örgütsel politikanın örgütsel adalet ve işten ayrılma niye tine etkisi. (Yayınlanmamış Yüksek Lisans Tezi). Gebze Yüksek Teknoloji Enstitüsü, Kocaeli.

Adams, J.S. (1965). Inequity in social exchange. İçinde L. Berkovitz (Ed.), Advances in experimentalsocial psychology(Cilt.2, ss. 267299). New York: AcademicPress.

Andrews, M.C. ve Kacmar, K.M. (2001).Discriminating among organiza tional politics, justice and support. Journal of Organizational Behavior,22, 347366.

Baron, R. M. ve Kenny, D. A. (1986). The moderator mediator variable distinction in social psychological research: Conceptual, strategic and statistical considerations. Journal of Personality and Social Psychology, 51, 1173-1182.

Blau, M.P. (1964). Exchange and Power in Social Life. New York: Wiley.

Bodla, M. ve Danish, R.Q., (2009).Politics and workplace: An empirical examination of the relationship between perceived organizational politics and work performance. South Asian Journal of Management, 16, 44-62

Brown, T. A. (2006). Confirmatory factor analysis for applied research. New York: The Guilford Press.

Buchanan, D.A. (2008). You stab my back, I'll stab yours: Management experience and perception of organization political behaviour. British Journal of Management, 19, 49-64.

Byrne, Z.S. (2005). Fairness reduce the negative effects of organizational politics on turnover intentions, citizenship behavior and job performance. Journal of Business and Psychology,20, 175-200.
Chan, C.H., Rosen, C.C. ve Levy, P.E. (2009). The relationship between perceptions of organizational politics and employee attitudes, strain, and behavior: A metaanalytic examination. Academy of Management, 52, 779-801.

Colquitt, J., LePine, J.A., Piccolo, R.F., Zapata, C.P. ve Rich, B.L. (2011). Explaining the justiceperformance relationship: Trust as exchange deepener or trust as uncertainty reducer?. Journal of Applied Psychology, 21, 1-15.

Cropanzano, R.S., Kacmar. K.M. ve Bozeman, D.P. (1995).Organizational politics, justice, and support: Their differences and similarities (pp. I-IX). İçinde R.S. Cropanzano \& K.M. Kacmar (Eds.).Organizational politics, justice, and support: Managing social climate at work. Westport, CT: Quorum Books.

Cropanzano, R., Howes, J. C., Grandey, A.A. ve Toth, P. (1997).The relationship of organiza tional politics and support to work behaviors, attitudes, and stress. Journal of Organizational Behavior, 18, 159-180.

Drory, A. ve Romm, T. (1989).Politics in organization and its perception within the organization. Organization Studies, 9,165179.

Drory, A. (1993). Perceived political climate and job attitudes. Organizational Studies 14,59-71.

Farh, J., Podsakoff, P.M. ve Organ, D. W. (1990). Accounting for organizational citizenship behavior: Leader fairness and task scope versus satisfaction. Journal of Management, 16, 705-21.

Ferris, G.R. ve Kacmar, K.M.(1992). Perception of organizational politics. Journal of Management, 18, 93-116.

Ferris, G.R., Fedor, D.B., Chachere, J. G. ve Pondy, L. R. (1989). Myths and politics in organizational contexts. Group and Organization Studies, 14, 83-103.

Ferris, G.R., Frink, D.D., Galang, M.C., Zhou, J., Kacmar, K.M. ve Howard, J.E. (1996). Perceptions of organizational politics: Prediction, stress-rela ted implications, and outcomes. Human Relations, 49, 233-266. 
Grant, A.M. ve Mayer, D.M. (2009). Good soldiers and good actors: Prosocial and impression management motives as interactive predictors of affiliative citizenship behaviors. Journal of Applied Psychology,94, 900-912.

Greenberg, J. (1987). A taxonomy of organizational justice theories. Academy of Management Review, 12, 9-22.

Gürbüz, S. (2007).Yöne ticile rin örgütsel va tandaşlık davranışlarının iş tatmini ve algıladıkları örgütseladalet ile ilişkisi. (Yayınlanmamış Doktora Tezi). İstanbul Üniversitesi; İstanbul.

Gürbüz,S., Mert, İ.S.,(2009).Örgütsel adalet ölçeğinin geçerlik ve güvenirlik uygulaması: Kamuda görgül bir çalışma. Amme İdaresi Dergisi, 42, 117-139.

Harris, K.J., Andrews, M.C. ve Kacmar, M.K. (2007). The moderating effects of justice on the relationship between organizational politics and work place attitude. Journal of Business Psychology, 22, 135- 144.

Hochwarter, W.A., Witt, L.A. ve Kacmar, K.M. (1997).Perceptions of organizational politics as a moderator of the relationship between conscientiousness and job performance. Southern Management Association Meeting, Atlanta, GA.

Homans, G.C. (1961 ). Social behavior: Its elementary forms. New York: Harcourt, Brace, and World.

İşcan, Ö.F. (2005). Siyasal arena metaforu olarak örgütler ve örgütsel siyasetin örgütsel adalet algisına etkisi. Ankara Üniversitesi Siyasal Bilgiler Fakültesi Dergisi, 60, 149-171.

Jöreskog, K.G. ve Sörbom, D. (2006). LISREL 8.8 for Windows [Computer software]. Skokie, IL: Scientific Software International, Inc.

Kacmar, K.M. ve Ferris, G.R. (1991). Perceptions of organizational politic sscale (POPS): Development and construct validation. Educational and Psychological Measurement, 51, 193-205.

Kacmar, K.M. ve D.S. Carlson (1997). Further validation of the perceptions of politicsscale (POPS): A multiple sample investigation. Journal of Management, 23, 627- 658.
Kline, R. B. (2005). Principles and practice of structural equation modeling (2 nd ed.). New York: The Guilford Press.

Luo, Y. (2007). The independent and interactive roles of procedural, distributive and interactional justice in strategic alliances. Academy of Management Journal, 50, 644-664.

Mayes, B.T. ve Allen, R.W. (1977).Toward a definition of organizational politics. Academy of Management Review, 2, 672-678.

Niehoff, B.P. ve Moorman, R.H. (1993).Justice as a mediator of the relationship between methods of monitoring and organizational citizenship behavior. Academy of Management Journal, 36, 527-556.

Organ, D.W. (1988). Organizational citizenship behavior. Lexington, MA: Lexington Books.

Organ, D.W. ve Konovsky, M. (1989). Cognitive versus affective determinants of organizational citizenship behaviour, Journal of Applied Psychology, 74, 157-164.

Özdevecioğlu, M. (2002). Kamu ve özel sector yöne ticile ri a rasındaki da vranışsal ça lışma koşulları ve kişilik farklılıklarının belirlenmesine yönelik bir araştırma. Erciyes Üniversitesi İktisadi ve İdari Bilimler Fakültesi Dergisi, 19, 115-134.

Parker, C.P., Dipboye, R.L., ve Jackson, S.L. (1995). Perceptions of organizational politics: An investigation of antecedents and consequences. Journal of Management, 21, 891-912.

Ram, P. ve Prabhakar, G.V. (2010).Leadership styles and perceived organizational politics as predictors of work related outcomes. European Journal of Social Sciences, 15, 40-55.

Randall, M.L., Cropanzano, R., Borman, C.A. ve Birjulin, A. (1999). Organizational politics and organizational support as pre dictors of work attitudes, job performance, and organiza tional citizenship behavior. Journal of Organizational Behavior, 20, 159-174.

Rosen, C.C., Levy, P.E. ve Hall, R.J. (2006). Placing perceptions of politics in the context of the feedbackenvironment, employee attitudes, and job performance. Journal of Applied Psychology, 91, 211-220.

Sargut, A.S. (2010). Kültürlerarası farkllaşma ve yönetim. Ankara: İmge Kitabevi Yayınları. 
Sert, M. (2013).Örgütsel adalet, bağlllık ve örgütsel vatandaşlık davranışı ilişkisi üzerine bir meta-analizi. (Yayımlanmamış Yüksek Lisans Tezi). Kara Harp Okulu, Ankara.

Songür, N., Basım, H.N. ve Şeşen, H. (2008). Örgütselva tandaşlık davranışında a daletin öncüllük rolü. Amme İdaresi Dergisi, 41, 79100.

Yen, W.W., Chen, S.C. ve Yen, S.I. (2009).The impact of perceptions of organiza tional politics on workplace friendship. African Journal of Business Management, 3, 548-554.

Tyler, T.R. ve Lind, E.A. (1992).A relational model of authority in groups. İçinde M.P. Zanna (Eds.), Advances in experimental social psychology (ss. 115-191). 25 San Diego, CA: Academic Press.

Vigoda, E. (2000). Organizational politics, job attitudes, and workout comes: Exploration and implications for the public sector. Journal of Vocational Behavior 57, 326 -347.

Vigoda-Gadot, E. ve Talmud, I. (2010). Organizational Politics and Job Outcomes: The moderating effects of trust and social support. Journal of Applied Social Psychology, 40, 2829-2861.

Williams, L.J. ve Anderson, S.E. (1991). Job satisfaction and organizational commitment as predictors of organizational citizenship and in-role behaviors, Journal of Management, 17, 601617. 